\title{
Direct Spectrophotometric determination of Copper (II) in leaf, fruit, alloy and biological samples using 5-Bromo-2-hydroxy-3- methoxybenzaldehyde-P-hydroxybenzoic hydrazone
}

\author{
Madhavi devireddy, B. Saritha and Prof. T. Sreenivasulu Reddy* \\ Department of Chemistry, Sri Krishnadevaraya University, Anantapur 515003 (A.P), India
}

\begin{abstract}
Bromo-2-hydroxy-3-methoxybenzaldehyde-p-hydroxybenzoichydrazone reacts with $\mathrm{Cu}(\mathrm{II})$ forming brown coloured soluble complex in aqueous dimethyl formamide in the pH range 3.0-8.0. It has a $\lambda_{\max }$ at $405 \mathrm{~nm}$. Studies were carriedout at $\mathrm{pH}-5.0$. The method obeys Beer's law in the range 0.317 to $3.81 \mu \mathrm{g} / \mathrm{ml}$. The molar absorptivity is $1.412 \times 10^{4} \mathrm{~L} \mathrm{~mol}^{-1} \mathrm{~cm}^{-1}$ and Sandell's sensitivity is $0.0045 \mu \mathrm{g} / \mathrm{cm}^{2}$. The standard deviation of the method for ten determinations of $1.59 \mu \mathrm{g} / \mathrm{ml}$ of $\mathrm{Cu}(\mathrm{II})$ is $1.22 \times 10^{-3}$. The correlation coefficient $(\gamma)$ of the calibration equation of the experimental data is 0.9999. The effect of various diverse ions is studied. The formula of the complex is 1:1 and its stability constant is $3.13 \times 10^{5}$. Based on the above, a rapid, simple, sensitive and selective direct visible spectrophotometric method has been developed. The method developed was used for the determination of copper(II) in alloy, fruit, leaf and biological samples. The results are in good agreement with the certified values.
\end{abstract}

Key words: $\mathrm{Cu}(I I)$,Direct visible spectrophotometric determination,5-BHMBHBH. Alloy samples, fruit, leaf and biological samples.

\section{Introduction :}

Copper is an essential element for plants, animals and in biological systems ${ }^{1}$. Apart from the biological utility of copper, it also finds applications in industries ${ }^{2}$. Copper occurs naturally in most vegetables, meat and fruits. The study of copper in food items is of importance as it place definite role in regulating vital biological process $^{3-4}$. A variety of clinical disorders have been reported due to dietary deficiency of copper. They include anemia, bone disorders, depigmentation of hair, heart failure and gastro-intestinal disorders ${ }^{5-6}$. In view of this there is a need for rapid and sensitive methods for the analytical estimation of copper. In recent years, many methods such as electro thermal atomic absorption spectrometry ${ }^{7}$, spectrophotometric flow injection method ${ }^{8}$, phosphorescence quenching method ${ }^{9}$, atomic absorption spectrometry after on-line solid phase extraction ${ }^{10}$, cloud point extraction and after that spectrophotometric determination ${ }^{11}$, flow-injection chemiluminescence ${ }^{12}$, optical fiber reflectance sensor ${ }^{13}$, thermospray flame furnace-atomic absorption spectrometry after online sorbent pre concentration ${ }^{14}$, voltammetry ${ }^{15-17}$, simple atomic absorption spectrometry ${ }^{18-25}$ and inductive coupled plasma atomic emission spectrometry ${ }^{26-28}$. However, these techniques suffer from the disadvantages of high cost, operational complexity and labourious experimental procedures. Spectrophotometry still represents an attractive technique for the determination of metal ions because of its simplicity, low cost and easy availability $^{29}$. Several reagents $\mathrm{s}^{30-39}$ are reported for the spectrophotometric determination of copper. Several authors ${ }^{40-41}$ have critically reviewed the disadvantages such as use of solvent extraction, use of surfactants, low sensitivity and interference from diverse ions, of the various reagents employed for the spectrophotometric determination of copper. Thus, there is a need for the development of highly sensitive and selective direct spectrophotometric methods for the determination of copper in the several Singh et.al ${ }^{42}$ have reviewed critically for the potential analytical applications of hydrazone derivatives. A review of the literature revealed that very few 4-hydroxy benzoic hydrazones have been employed ${ }^{41,43}$ for the determination of copper in several real samples. In view of this we now report a simple, sensitive, selective and rapid spectrophotometric procedure for the determination of copper in plant leaves, fruits and alloy samples using a new chromogenic hydrazone 5Bromo-2-hydroxy-3-methoxybenzaldehyde-4-hydroxybenzoichydrazone.

\section{Experimental:}

The chromogenic reagent,5-bromo-2-hydroxy-3-methoxybenzaldehyde-phydroxybenzoichydrazone was synthesized in the laboratory by condensing 5 - Bromo-2-hydroxy-3methoxybenzaldehydeand p-hydroxybenzoic hydrazone. A 0.01M DMF solution of the reagent is used in the studies.

$0.01 \mathrm{M}$ stock solution of $\mathrm{Cu}(\mathrm{II})$ was prepared by dissolving requisite amount of copper sulphate (AR,Glaxo) in distilled water and standardized volumetrically ${ }^{44}$. The working solutions were prepared 
by diluting the stock solutions with distilled water. Buffer solutions of $\mathrm{pH} 5.0$ were prepared by mixing $0.2 \mathrm{M}$ sodium acetate and $1.0 \mathrm{M}$ acetic acid in suitable proportions and the $\mathrm{pH}$ was adjusted by a $\mathrm{pH}$ meter.

The absorbance and $\mathrm{pH}$ measurements were made on a Perkin Elmer (LAMDA 25) UV-Visible spectrophotometer (Model UV-160A) controlled by a computer fitted with $1 \mathrm{~cm}$ path length quartz cells and an ELICO digital pH meter of (Model LI 613) respectively.

\section{Procedure:}

To $5 \mathrm{ml}$ of buffer solution (pH 5.0) $0.5 \mathrm{ml}$ of 5-BHMBHBH $\left(1 \times 10^{-2} \mathrm{M}\right)$ in DMF, $1.5 \mathrm{ml}$ of DMF were taken in each of a set of $10 \mathrm{ml}$ volumetric flasks, varying amounts of $\mathrm{Cu}$ (II) were added and diluted to $10 \mathrm{ml}$ in a volumetric flask with distilled water. The absorbance of these solutions was measured at $405 \mathrm{~nm}$ against reagent blank and plotted against the amount of copper. A straight line is obtained and corresponded to the equation $\mathrm{A}_{405}=0.2203 \mathrm{C}+0.0016$. ( $\mathrm{C}$ is the amount of copper in $\mu \mathrm{g} / \mathrm{ml}$ ).

\section{Results and discussions:}

5-bromo-2-hydroxy-3-methoxybenzaldehyde-4-hydroxy benzoichydrazone (5-BHMBHBH) was used for the spectrophotometric determination of the copper(II). Copper(II) reacts with 5-BHMBHBH in the $\mathrm{pH}$ range 3.0-8.0 to form brown coloured complex. The absorption spectra of 5-BHMBHBH and its copper (II) complex under the optimum conditions were recorded in the range $360-500 \mathrm{~nm}$ and shown in Figure1.The copper (II)-5-BHMBHBH complex shows maximum absorbance at $405 \mathrm{~nm}$, where the reagent has negligible absorbance. The colour formation is instantaneous. It is stable for 48 hours. The analytical measurements were made at $\mathrm{pH} 5.0$ as at this $\mathrm{pH}$ the interference due to diverse ions is minimum. The order of addition of various constituents such as the buffer, the metal ion, the reagent has no effect on the maximum intensity of the colour reaction. A five fold molar excess of the reagent is sufficient to produce maximum absorbance. The formula of the complex was ascertained from jobs and molar ratio methods as 1:1. The stability constant of the complex is $3.13 \times 10^{5}$.

\section{Analytical characteristics of [Cu(II)-5-BHMBHBH] and the effect of foreign ions:}

The molar absorptivity, Beer's law range, detection limit, determination limit etc., are shown in the Table- 1 . The data indicate that the method is highly sensitive.

The effect of various foreign ions on the absorbance of the experimental solution containing $1.590 \mu \mathrm{g} / \mathrm{ml}$ of $\mathrm{Cu}(\mathrm{II})$ was studied and the results are presented in Table.2. All the anions studied except thiosulphate, oxalate, ascorbate and EDTA do not interfere even if they are present in more than 100 fold excess. Many cations except $\mathrm{Fe}$ (III) and Ti(IV) do not interfere in the determination of $\mathrm{Cu}$ (II) even in more than 10 fold excess. However 20 fold excess of Ti(IV) and 50 fold excess of Fe(III) could be masked using fluoride and tartarate respectively.

\section{Applications:}

The proposed method was applied for the determination of copper(II) in grape leaf, banana fruit, biological samples and in some alloy and steel samples.

\section{Preparation and analysis of Alloy and Steel Samples:}

A $0.1-0.5 \mathrm{~g}$ of the sample is dissolved in a mixture of $2 \mathrm{ml} \mathrm{HCl}$ and $10 \mathrm{ml} \mathrm{HNO}_{3}$. The resulting solution is evaporated to a small volume. To this $5 \mathrm{ml}$ of $1: 1 \mathrm{H}_{2} \mathrm{O}: \mathrm{H}_{2} \mathrm{SO}_{4}$, mixture is added and evaporated to dryness. The residue is dissolved in $15 \mathrm{ml}$ of distilled water and filtered through Whatman filter paper No.41. the filtrate is collected in a $100 \mathrm{ml}$ volumetric flask and made up to the mark with distilled water. The solution is further diluted as required. Then a known aliquot of the sample was analysed by the general procedure. The results are presented in Table 3.

\section{Analysis of Grape leaves and banana fruit samples:}

The grape leaf and the banana fruit sample solutions are supplied by Andhra Pradesh Agricultural Research Institute (APARI) ,Hyderabad, India. An aliquot of the sample was analysed by the general procedure. The results are presented in Table 4.

\section{Preparation and analysis of biological samples:} a)Sheep liver:

$100 \mathrm{gm}$ of sheep liver is brought into solution by the following procedure.A weighed quantity of finely powdered dry sample is taken in a silica crucible and heated to oxidise organic matter. It is ashed at 
$550^{\circ} \mathrm{C}$ by keeping for 3-4 hours in a muffle furnace. The ash is dissolved in $10 \mathrm{ml}$ of $1: 1 \mathrm{HCl}$ by heating, filtered through an acid washed filtered paper into a volumetric flask and the residue is washed with water. The washings are also collected into a $100 \mathrm{ml}$ volumetric flask and finally made up to the mark with distilled water. The solution is diluted as required. An aliquot of the sample is analysed by the general procedure and the results are presented in Table 5.

\section{b)Buffalow milk:}

$100 \mathrm{ml}$ of the milk sample are added dropwise to a heated crucible to evaporate it without frothing. After the moisture has been removed, the contents are heated to $450^{\circ} \mathrm{C}$. It is then cooled and $1 \mathrm{ml}$ of concentrated nitric acid is added an ignited again at $450^{\circ} \mathrm{C}$ for one hour. The ash is dissolved in a minimum volume of dilute nitric acid and made up to the mark in a $10 \mathrm{ml}$ standard flask with distilled water. An aliquot of the sample is analysed by the general procedure and the results are presented in Table 5.

\section{Conclusions:}

The present direct spectrophotometric method determination of $\mathrm{Cu}(\mathrm{II})$ using 5-BHMBHBH is a new simple, highly sensitive and selective method. It can be easily applied for the determination of $\mathrm{Cu}$ (II) in alloy and steel samples, plant samples and biological samples.Although many sophisticated techniques such as pulse polarography, HPLC, AAS,ICP-AES, ICP-MS, etc. are available for the determination of aluminium at trave levels in numerous complex materials, factors such as the low cost of the instrument, easy handling,lack of requirement for consumables and almost no maintanance have caused spectrophotometry to remain a popular technique, particularly in laboratories of developing countries with limited budget. The sensitivity in terms of molar absorptivity and precision in terms of relative standard deviation of the present method are very reliable for the determination of copper in real samples.

\section{Acknowledgement:}

The authors thank the department of Chemistry of S.K.University, Anantapuramu, for providing the necessary facilities. One of authors (B.Saritha) thanks UGC for providing financial assistance under BSRB scheme.

Table 1.

Analytical characteristics of [Cu(II) - 5-BНМВНВН]

\begin{tabular}{|l|l|}
\hline \multicolumn{1}{|c|}{ Parameter } & \multicolumn{1}{c|}{ Direct method (405nm) } \\
\hline Beer's law range $(\mu \mathrm{g} / \mathrm{m} \mathrm{l})$ & $0.317-3.81$ \\
\hline Molar absorptivity $\left(\mathrm{L} \mathrm{mol}^{-1} \mathrm{~cm}^{-1}\right)$ & $1.412 \times 10^{4}$ \\
\hline Sandell's sensitivity $\left(\mu \mathrm{g} / \mathrm{c} \mathrm{m}^{2}\right)$ & 0.0045 \\
\hline Correlation coefficient $(\gamma)$ & 0.9999 \\
\hline Standard deviation & 0.0012 \\
\hline Y- intercept $(\mathrm{b})$ & 0.00154 \\
\hline Detection limit $(\mu \mathrm{g} / \mathrm{m} 1)$ & 0.008 \\
\hline Composition $(\mathrm{Metal}:$ Ligand) & $1: 1$ \\
\hline Stability constant $(B)$ & $3.13 \times 10^{5}$ \\
\hline
\end{tabular}

Table 2. Tolerance limits of foreign ions

\begin{tabular}{|c|c|c|c|}
\hline \multicolumn{2}{|c|}{ Amount of Cu (II) } & pH & \multirow{2}{*}{$\begin{array}{l}\mathbf{5 . 0} \\
\text { Tolerance limit } \\
\mu \mathrm{g} / \mathrm{ml}\end{array}$} \\
\hline Ion & $\begin{array}{l}\text { Tolerance limit } \\
\mu \mathrm{g} / \mathrm{ml}\end{array}$ & Ion & \\
\hline Tartarate & 2210 & $\mathrm{Mg}(\mathrm{II})$ & 2000 \\
\hline Citrate & 1800 & $\mathrm{Hg}$ (II) & 196 \\
\hline Fluoride & 1200 & $\mathrm{Al}$ (III) & 20 \\
\hline Iodide & 940 & W (VI) & 116 \\
\hline Sulphate & 910 & Cd (II) & 100 \\
\hline Bromide & 720 & Mn (II) & 50 \\
\hline Phosphate & 680 & Zn (II) & 48 \\
\hline Nitrate & 600 & $\mathrm{Ce}$ (IV) & 40 \\
\hline Carbonate & 590 & Co (II) & 24 \\
\hline
\end{tabular}


Direct Spectrophotometric determination of Copper (II) in leaf, fruit, alloy and biological ...

\begin{tabular}{|l|l|l|l|}
\hline Thiocyanate & 410 & $\mathrm{~Pb}(\mathrm{II})$ & 40 \\
\hline Chloride & 350 & $\mathrm{Se}(\mathrm{IV})$ & 30 \\
\hline Thiourea & 100 & $\mathrm{Te}(\mathrm{IV})$ & 26 \\
\hline Thiosulphate & Interferes & $\mathrm{Tl}(\mathrm{III})$ & 18 \\
\hline Oxalate & Interferes & $\mathrm{Ni}(\mathrm{II})$ & 12 \\
\hline Ascorbate & Interferes & $\mathrm{Cr}$ (VI) & 8 \\
\hline EDTA & Interferes & $\mathrm{Fe}(\mathrm{III})$ & $4 ; 60^{*}$ \\
\hline Th(IV) & 6 & $\mathrm{~V}(\mathrm{~V})$ & 17 \\
\hline Ti (IV) & 35 & $\mathrm{Zr}(\mathrm{IV})$ & 32 \\
\hline & & $\mathrm{Mo}(\mathrm{VI})$ & 4 \\
\hline
\end{tabular}

*Masked with tartrate

${ }^{\mathrm{a}}$ Masked with flouride

Table 3.

Determination of $\mathrm{Cu}$ (II) in Alloy and Steel samples

\begin{tabular}{|l|c|c|c|}
\hline \multirow{2}{*}{ Sample } & \multicolumn{2}{|c|}{ Composition (\%) } & \multirow{2}{*}{ Error (\%) } \\
\cline { 2 - 3 } & Certified & Found $*$ & +0.28 \\
\hline BCS $-179 / 2\left(\right.$ steel) ${ }^{\text {a }}$ & 58.00 & 58.16 & -1.95 \\
\hline BAS $-203^{\text {b }}$ & 04.10 & 04.02 & \\
\hline
\end{tabular}

*Average of five determinations.

a) $\mathrm{Cu} 58 \% ; \mathrm{Zn} 35.8 \% ; \mathrm{Al} 2.2 \% ; \mathrm{Fe} 1.2 \% ; \mathrm{Mn} 0.86 \% ; \mathrm{Ni0} 0.56 \% ; \mathrm{Sn} 0.7 \%$;Si0.044\% ;

b) $\mathrm{Cu} 4.10 \%$; Ni $1.93 \%$; Fe $0.43 \%$; Mn $0.29 \%$; Mg $1.61 \%$; rest Al.

Table 4.

Determination of $\mathrm{Cu}(\mathrm{II})$ in grape leaves and banana fruit.

\begin{tabular}{|l|c|c|c|}
\hline \multirow{2}{*}{ Sample } & \multicolumn{2}{|c|}{ Composition $\boldsymbol{\mu g} / \mathbf{m l}$} & \multirow{2}{*}{ Relative error (\%) } \\
\cline { 2 - 3 } & Certified & Found* & \\
\hline Leaf sample of grape $^{\mathrm{a}}$ & 55.40 & 55.55 & +0.27 \\
\hline Banana fruit sample $^{\mathrm{b}}$ & 1.67 & 1.66 & -0.60 \\
\hline
\end{tabular}

* Average of five determinations.

a) $\mu \mathrm{g} / \mathrm{ml} \mathrm{Zn} \mathrm{6.18;Cu} \mathrm{55.40;Mn20.0;Ca110;Mg} \mathrm{110;P} \mathrm{300;K1007;Fe} \mathrm{33.7.}$

b) $\mu \mathrm{g} / \mathrm{ml}$ Zn 1.12; Cu1.67; Fe 16.0 ;Mn 31.0 ;Ca 1300 ;Mg 290; P 170; K 1120.

Table 5.

Analysis of sheep liver, and buffalow milk

\begin{tabular}{|l|c|c|c|}
\hline \multirow{2}{*}{ Sample ** } & \multicolumn{2}{|c|}{ Composition (\%) } & \multirow{2}{*}{ Error (\%) } \\
\cline { 2 - 3 } & AAS method & $\begin{array}{c}\text { Present* } \\
\text { method }\end{array}$ & \\
\hline Sheep liver & 16.81 & 16.86 & +0.30 \\
\hline Buffalow milk & 04.10 & 04.06 & -0.98 \\
\hline
\end{tabular}

* Average of five determinations ** Amount in $1 \mathrm{gm}$.

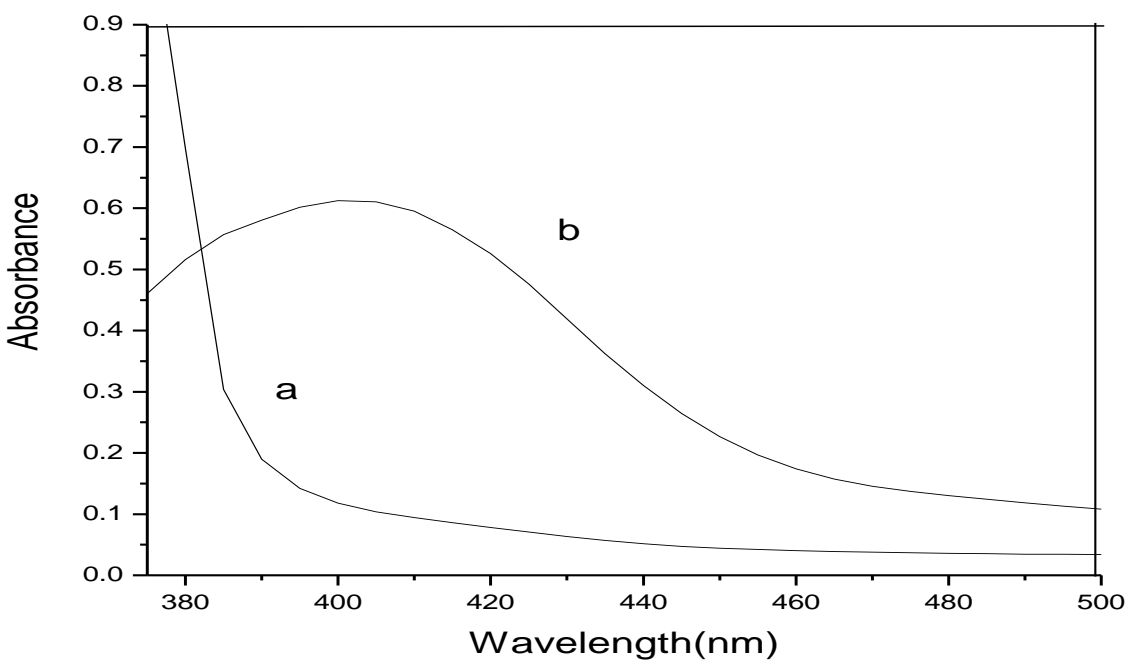

Fig: Absorption spectra of

a) 5-BHMBHBHVs buffer blank 
b) $[\mathrm{Cu}(\mathrm{II})]-5-\mathrm{BHMBHB}$ Vs reagent blank

$$
\begin{aligned}
& {[\mathrm{Cu}(\mathrm{II})]=5 \times 10^{-5} \mathrm{M}:[5-\mathrm{BHMBHBH}]=5.0 \times 10^{-3} \mathrm{M}} \\
& \mathrm{pH}=5.0
\end{aligned}
$$

\section{References:}

[1]. T.Z. Judith, T. Peter and T. Thomas, Immunotoxicology of Environment Occupational Metals. School of Environment Occupational Metals, School of Medicine, New York, 1998

[2]. B.K. Sharma, 1997. Environmental Chemistry. Goel Publishing House, Meerut, India.

[3]. P.L Malvankar and V.M. Shinde, Analyst., 1991, 116, 1084.

[4]. G.L. Eichhori, Inorganic biochemistry. New York, Elsevier Scientific Publishing Company, 1975.

[5]. P.A. Waldravens, Clin. Chem., 1980, 26, 189.

[6]. E.J. Underwood, Trace Elements in human and animal nutrition. 4th Ed. Academic Press,New York, 1979.

[7]. F. G. Pinto, D.Andrada, U. V .Rey, L. M. S .Ansaloni, J. B. B. Silva, Anal. Lett. 2006, 39, 2441-2445.

[8]. S. Lunvongsa, T .Takayanagi, M. Oshima, S. Motomizu, Anal. Chim. Acta, 2006, 576, 261-269.

[9]. J. M. Liu, X. Lin, S. S . Q. M .Xu, Lu, L. Q. Zeng,. S. Q. Lin, Spectrosc. Lett. 2006, 39,311-320.

[10]. N. Anthemidis, K. G. Ioannou, Anal. Chim. Acta 2006, 575, 126-131.

[11]. Y .Lai, Y.Yu, P. Zhong, J.Wu, Z. Long,; C. Liang, Anal. Lett. 2006, 39, 1201-1206.

[12]. V. A. Lemos, J. S.Santos, P. X. J. Baliza, Braz. Chem. Soc. 2006, 17, 30-35.

[13]. B. Li, D.Wang, J. Liv, Z.Zhang, Talanta 2006, 69, 160-165.

[14]. R. Sundari, M.Ahmad, L. Y. Heng, Sensor. Actuat. B-Chem. 2006, 113, 201-208.

[15]. M. Praveen Kumar, P. Chandra Mouli, S. Jayarami Reddy, Anal. Lett. 2005,38, 463.

[16]. C. L. Giancarlotorsi, Coll. Czech. Chem. Commun. 2003, 68, 1437,

[17]. G. Gillain, G. Duyckarets, A. Disteche, Anal. Chim. Acta 1979,106, 23.

[18]. Seung-Hynuntee, Hu-Sennchoi, Bull. Korean Chem. Soc. 2003, $21,1705$.

[19]. M. Soyak, Frensen's Environ. Bull. 1998, 7 , 383.

[20]. N. Pourreza, K. Ghanemi, Spectroscopy Lett. 2006,39, 127.

[21]. M. A. Taher, S. Z. M. Moberakeh, A. R. Mohamedesi, Turk. J. Chem. 2005, 29 , 17.

[22]. Y. Bakireioglu, D. Bakireiouglu, S. Akman, Anal. Lett. 2004,37, 1937.

[23]. V. K. Jain. S. S. Sait, P. Shrivastav, Y. K. Agrawal, Talanta1997, 45, 397.

[24]. A. E. Watson, Nucl. Active 1984, 30, 31.

[25]. D. T. E. Hunt, A. L. Wilson, The Chemical Analysis of Water, The Royal Society of Chemistry, Oxford 1986,398 ,

[26]. Y. Gub, B. Din, Y. Liu, X. Chang, S. Meng, Talanta 2004, 62 , 209.

[27]. Y. Liu, P. Liang, L. Guo, Talanta 2005, 68, 25.

[28]. A. Ramesh, K. Ramamohan, K. Seshaiah, N. D. Jaya kumar, Anal. Lett. 2001,34, 219.

[29]. S .E. Ghazy and G. A. E. Mostafa, Egypt J Chem., 2002,45, 855

[30]. Z.K. Qiao, Q. Z.Hou and Lihua Jianyan, Hvaxue Fence, 1995, 31(2), 105.

[31]. P. P. Sun and B. C. Wu, Fenxi Shiyanshi, 1994, 13(5), 11.

[32]. F .Captain Gareia, Captain - L. F. Vallvey, Gines - D.Fernandez and H. P. Espinosa, Quim Anal., 1988, 7(4), 451.

[33]. A .Noroles, L.Valladares and Z .Fresenius, Anal Chem., 1989, 334(1), 53-55.

[34]. F.Molina, G. D. Fernandez, Bosque - M. J. B. Sendra and P .Espinosa, J Pharm Biomed Anal., 1988, 6(6-8), 1099.

[35]. M .I .Karayannis, Talanta, 1994, 41(10), 1645-1649.

[36]. V. M. Shinde and S. M. Khopkar, Anal Chem., 1969, 41(2), 342.

[37]. K.Terashima and H.Tomioka, Jap Anal., 1969, 18(8), 998.

[38]. G.S. Katiyar and B .C. Haldar, Indian J Chem Soc., 1984, 61(4), 353-355.

[39]. G .Ramanjaneyulu, P .Ravendra Reddy, V .Krishna Reddy and T. Sreenivasulu Reddy, The Open Anal Chem J., 2008, 2, 78-82.

[40]. V.Srilalitha, A.Raghavendra Guru Prasad, K. Ramana Kumar, V. Seshagiri and L.K. Ravindranath, Ovidius Uni.Annals of Chem.,2011,22(1),5-10.

[41]. K.Ramakrishna Reddy, N. Devanna, K.B.Chandrasekhar, Int.J.ChemTech.Res,.2011,3(4).

[42]. R.B. Singh, P .Jain, R.P.Singh, Talanta, 1982, 29, 77-84.

[43]. D. Gopalkrishna,N. Devanna,B. Chandrasekhar, Int.J.Anal and bioanal.Chem.,2011,1(1),19-24.

[44]. A.I.Vogel, “A text book of quantitative inorganic analysis", $4^{\text {th }}$ Edn. ELBS and Longman,1978,447. 